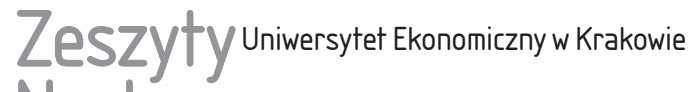 Naukowe
}

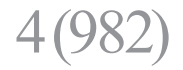

ISSN 1898-6447

e-ISSN 2545-3238

Zesz. Nauk. UEK, 2019; 4 (982): 77-93

https://doi.org/10.15678/ZNUEK.2019.0982.0405

Beata Glinkowska-Krauze

Iegor Chebotarov

Viacheslav Chebotarov

\section{Paths to Internationalisation of Small and Medium-sized Enterprises in Ukraine}

\begin{abstract}
Objective: The defining objectives of the study are the following three. First, to classify the level of real development of internationalisation in Ukrainian SMEs. To accomplish this goal, the authors summarise the theory and methodology defining the field of internationalization. They also present their own empirical studies on Ukrainian small and medium-sized enterprises (SMEs). Second, they analyse the main forms, motivational factors and barriers to the internationalisation of Ukrainian SMEs. Finally, they discuss
\end{abstract}

Beata Glinkowska-Krauze, University of Lodz, Faculty of Management, Narutowicza 68, 90-136 Łódź, Poland, e-mail: beata.glinkowska@uni.lodz.pl, ORCID: https://orcid.org/0000-00026915-3297.

Iegor Chebotarov, Luhansk Taras Shevchenko National University, Department of Economics, Marketing and Entrepreneurship, 1 Gogol Square Starobil's'k, Luhansk Region 92703, Ukraine, e-mail: iegor.chebotarov@gmail.com, ORCID: https://orcid.org/0000-0001-5963-7637.

Viacheslav Chebotarov, Luhansk Taras Shevchenko National University, Department of Economics, Marketing and Entrepreneurship, 1 Gogol Square, Starobil's'k, Luhansk Region 92703, Ukraine, e-mail: vena.lnu@gmail.com, ORCID: https://orcid.org/0000-0003-1131-9116.

This is an open access article distributed under the terms of the Creative Commons Attribution-NonCommercial-NoDerivatives 4.0 License (CC BY-NC-ND 4.0); https://creativecommons.org/ licenses/by-nc-nd/4.0/ 
the development of strategies and mechanisms for activating the internationalisation of SMEs in Ukraine.

Research Design \& Methods: The study used qualitative research, including a survey of the literature and our own empirical research (detailed interviews with Ukrainian entrepreneurs, survey questionnaire, and experimental assessments of scientists from Ukraine and Poland on this subject).

Findings: The present condition of the internationalisation of Ukrainian small and medium-sized enterprises is assessed, and its obstacles and motives have been identified. In the context of the European Union's experience in regulating small and medium-sized businesses, the most promising strategies and sectors of the economy have been classified. It is in these sectors that Ukrainian small and medium-sized enterprises should gain the greatest competitive advantages. Lastly, mechanisms for promoting the internationalisation of Ukrainian SMEs are defined.

Implications / Recommendations: In modern conditions the internationalisation of Ukrainian small and medium-sized enterprises is at an early stage. It does currently extend substantively beyond export-import operations. In Ukraine, enterprises that internationalise tend to do so upon or near their inception. The main approach to stimulating the internationalisation of Ukraine's SME sector is to develop effective state regulatory policy adapted to the contemporary norms and standards of the European Union. The results of the study have shown that Ukrainian SMEs can gain their greatest competitive advantages in the global market in industries including agriculture (primarily, "eco" and "green"), alternative and renewable energy production and IT technologies.

Contribution: Research fills a research gap in the field of internationalisation of Polish and Ukrainian small and medium-sized enterprises.

Keywords: internationalisation, enterprise, entrepreneurship, small and medium-sized enterprises, state regulatory policy, barriers, motives, strategies, international division of labour, Ukraine.

JEL Classification: D22, D 210, F 110, F230.

\section{Introduction and Research Methods}

The evolution of the market system explicitly demonstrates that the internationalisation of business structures across countries, as a voluminous and multi-level process of those structures interacting commercially, involves the formation of necessary prerequisites, primarily within domestic national markets. The signing in 2014 of the Agreement on Deep and Comprehensive Free Trade Areas (DCFTA) between the European Union and Ukraine opens up wide possibilities for integration activities for enterprises in Ukraine, including small and medium-sized enterprises (SMEs). However, for the practical implementation of the integration, Ukrainian enterprises must themselves meet certain parameters of modern European economic policy (and of the modern world economy as a whole). That is, 
enterprises in Ukraine must meet not only the conditions of the Small Business Act for Europe, but also the current Strategy of united Europe, "Europe 2020".

The internationalisation of Ukrainian SMEs is an imperfect process due not only to the insufficient resource potential of such enterprises, but also to the state's inability as the supreme institutional subject of the economy. Consequently, the main direction of stimulating the internationalisation of Ukrainian small and medium-sized enterprises and increasing its socio-economic impact is the development of an effective state regulatory policy governing SMEs adapted to the EU's current norms and standards. This is the hypothesis of this paper.

The article foregoes presenting the well-known theory on the development of SMEs, but does identify, using empirical studies conducted by the authors, the real problems and prospects of internationalisation of Ukraine's SMEs. The objectives were the following. First, to classify the level of real development of internationalisation in the country's small and medium-sized business sector. This will be accomplished by briefly summarising the theoretical and methodological material existing in literature and presenting the authors' own empirical studies of Ukrainian small and medium-sized enterprises. Second, the article examines the main forms, motivational factors and barriers of internationalisation of Ukrainian SMEs. Finally, it discusses the initial basis for developing prospective strategies and mechanisms behind the activation of internationalisation for Ukraine's SMEs.

It should be noted that problems facing the study of economics in Ukraine, due to a combination of factors, has only began to receive systematic research.

Organisational, economic, financial, and managerial aspects of the internationalisation of SMEs in Ukraine remain relatively insufficiently explored. This can be attributed to the lack of real applied empirical elaborations and predictive proposals. Issues surrounding the adaptation of legislation, technical norms and quality standards into the practice of Ukrainian enterprises have been studied by R. Džabraělov and V. Nověkova (2015, pp. 36-39), Epifanova (2009, pp. 211-215), G. Leh, M. Ěl'čišin and O. Turkalo (2011, pp. 224-229) and V. Lyashenko, A. Tolmachova and O. Kvilinskyi (2016, pp. 155-164).

In other research, Orekhova and Koshelenko have considered the development of SMEs in the conditions of internationalisation of the Ukrainian economy (Orekhova \& Koshelenko 2010, pp. 170-176). In this context, attempts to clarify the harmonisation of Ukrainian legislation with the norms and standards of the European Union should be noted (Glinkowska \& Chebotarov 2016, pp. 153-164). Examples of a systematic analysis of the internationalisation prospects of small and medium-sized businesses in Ukraine in modern conditions are rare. On a positive note, however, they are based on a study of Polish-Ukrainian cooperation (Glinkowska 2018), which profiled the entrepreneurial culture of managers in Poland and Ukraine (Glinkowska \& Chebotarov 2018, pp. 63-74; 
2019, pp. 75-86). The main methods used for the paper were qualitative research methods. It looks at the history of SMEs in Ukraine as well as the motivational factors and barriers to internationalisation of Ukrainian small and medium-sized enterprises in modern conditions. In addition to these qualitative factors, empirical research was also conducted. It was based on a questionnaire done at Ukrainian small and medium-sized enterprises that have already gone through the process of internationalisation, as well as detailed interviews with Ukrainian entrepreneurs and experimental evaluations among scientists from Ukraine and Poland on this subject.

This article was prepared on the basis of developments of the Center for Research Cooperation Poland-Ukraine. The Center was created in 2016, in a collaboration between the Department of Management of the University of Lodz (Łódź, Poland) and the Department of Economics, Marketing and Entrepreneurship of the Luhansk Taras Shevchenko National University (Starobil's'k, Ukraine). The basis of the cooperation was a framework agreement between the respective universities, signed in 2014.

The empirical research was carried out directly by the authors in Ukraine in the years 2015-2019, and included the following components.

First, a field study has been conducted on a sample of 75 small and medium-sized Ukrainian enterprises that already cooperate with foreign entrepreneurs. Overall, 2.6 times more Ukrainian SMEs were interviewed, yielding a sample rate of 197 . However, only 75 , or $38.1 \%$ of the 197 overall, had real experience in international relations. The rest (61.9\%) only had plans to expand internationally. While they had concluded protocols of intent with prospective partners and/or had made or received certain commercial offers, they had not yet begun to implement them.

In keeping with "experimental purity", the sampling index 75, rather than 197, is used in the calculations below.

An analysis of the data of the Main Directorates of State Statistics Services for the regions in which empirical studies were conducted showed that in these regions the number of SMEs officially participating in foreign economic activity was only 549 . That is, about $13.7 \%$ (75 of 549) of the sample size, a relatively high representativeness.

The SMEs surveyed (by industry sectors) were in agriculture, trade, construction and installation, tailoring and automotive servicing. In terms of their resource parameters and their approach to business, the enterprises selected for the empirical research are typical of their industries. They had been on the market for between 3 and 7 years.

In terms of location, the enterprises covered all the large regions of Ukraine: the southeast - Luhansk and Donetsk regions (both of which are under control of Ukrainian government and aren't yet directly involved in the military conflict in 
the Donbas); central Ukraine, including Kyiv, and west Ukraine, including the Lviv region. To ensure validity, the 75 enterprises represent the same four regions of the country in approximately equal proportions. Thus, the empirical research covers all of Ukraine's main region, thus enabling us to take into account, in addition to the economic characteristics of SMEs in Ukraine, the complex of the country's institutional features.

There were three main methodological instruments used in the research: an ad hoc survey questionnaire form, a standardised interview questionnaire form, which gave interviewees the opportunity for free expressions and comments, and detailed interviews conducted with several groups of experts in Ukraine.

The first group of experts consisted of representatives of various levels of state powers (district - poviat, region - voivodeship and Verkhovna Rada of Ukraine Parliament), whose responsibilities include implementing state regulatory policy associated with entrepreneurship.

The second group of experts comprised business coaches and analysts specialising in small and medium-sized business projects (in particular ones associated with the leading Ukrainian school of business at the Kyiv-Mohyla Academy as well as international philanthropic organisations providing grant support to small and medium-sized business in the Luhansk and Donetsk regions - Mercy Corps and FAO - The UN Food Organisations).

The third group of experts comprised representatives of the scientific community, whose research interests included the development of SMEs. In particular, the Polish-Ukrainian seminar "Theoretical and practical problems of management in Ukraine in the context of the implementation of the European integration course" was held on the basis of the Institute of Industrial Economics of the National Academy of Sciences and the Academy of Economic Sciences of Ukraine.

The official data and reports from the State Statistics Service of Ukraine and the information provided in the documentation of the Kyiv and Luhansk oblasts on the status of the issues selected for research was investigated (eg. the state of exports and imports, foreign direct investment, number of international projects carried out, etc.). The basic research question was, how do SMEs enter foreign markets? What are their strategies and motives and what are the barriers to internationalisation?

\section{The SME Sector in Ukraine: How It Functions and the Role It Plays in the Country's Economy}

The regulatory and legal basis for conducting business in Ukraine by small and medium enterprises is the Commercial Code of Ukraine, adopted in 2003 (https:// 
ips.ligazakon.net/document/view/T030436?bl=, accessed: 13 February 2020). The classification criteria adopted in Ukraine concerning employees and revenue volume are the same as in Poland and the EU. Hence, in this respect (as well as in relation to the establishment of criteria for medium and large businesses), the legislation of Ukraine has already been harmonised with the legislation of the European Union (Glinkowska \& Chebotarov 2016, pp. 148-158). No solid studies have been done on the internationalisation of enterprise activities in Ukraine (their strategies, forms, motives, barriers) or on models for the internationalisation of small and medium-sized businesses. Filling this gap, this study presents a classification of the actual condition and key problems of SMEs in Ukraine in the context of developing internationalisation policy. It also identifies the most important prerequisites and mechanisms for the practical implementation of such policy.

Entrepreneurship is an important and integral component of a market economy. It mobilises resources and accelerates the pace of development. The level of entrepreneurship in each country depends on the number and condition of enterprises. SMEs are the core of most market economies, which in many economically developed countries produce approximately 50\% of GDP (GUS: https://stat.gov. $\mathrm{pl} /$ obszary-tematyczne/podmioty-gospodarcze-wyniki-finansowe/, accessed: 13 February 2020).

In Ukraine, SMEs account for 15\% of GDP, a very low figure (Epifanova 2009, pp. 211-215). It should be mentioned that in 2014 GDP in Ukraine was minus (6.6\%), in 2015 (9.8\%) in 2016, 2.3\%, in 2017, 2.2\% and in 2018, 3,3\%. As of February 2020, the rough preliminary assessments for 2019 are between 2,7\% and 3\%. These data show that the economy has stabilised since 2016. 2020-2021 GDP for Ukraine is forecast to range between $3 \%$ and $3.8 \%$, respectively (The World Bank, https://data.worldbank.org/indicator/NY.GDP.MKTP.KD.ZG?locations=UA, accessed: 13 February 2020; International Monetary Fund, https://www.imf.org/external/datamapper/NGDP_RPCH@WEO/OEMDC/UKR, accessed 13 February 2020).

This may portend a positive climate for investing in Ukraine.

Entrepreneurs in Ukraine face a number of barriers to the development of their own businesses. The barriers are mainly related to a lack of equity and relatively high interest rates on loans (up to 24\%), making it difficult to finance foreign capital in the form of loans. There is also a lack of significant support from the government and an unfavorable economic and political situation. Two of Ukraine's oblasts (regions), Donetsk and Lugansk, face the most difficult straits, mainly due to the military operations being conducted there. However, the unstable operating conditions SMEs face is why about $80 \%$ of them end their operations with one to two years of setting up shop (Chukhray 2013, pp. 45-60). According to data from the official website of the State Statistics Service of Ukraine, almost $40 \%$ of 
small enterprises are barely profitable or entirely unprofitable. Enterprises in the construction industry and general industry are the least profitable. The employment rate in small enterprises has also fallen from year to year (State Statistics Service of Ukraine, http://www.ukrstat.gov.ua/, accessed: 13 February 2020). There are a number of reasons for the fall: the introduction of new technologies, high taxes, the robust "shadow economy" and the low profitability of enterprises and the related need to reduce costs. It is also worth noting that a fair number of small and medium-sized enterprises are known to artificially lower the profitability they declare.

In terms of successes, relatively small companies operating in agriculture, trade and the service industry are the most profitable. Furthermore, no deterioration in the indicator related to declining profitability of small and medium-sized enterprises. Since the global crisis (2008 to the present), product sales value and average annual salaries have improved while small enterprises have generally increased operating profitability (State Statistics Service of Ukraine, http://www.ukrstat.gov.ua/, accessed: 13 February 2020).

The robust grey zone, corruption and the monopolisation of the economy by large state enterprises together function is both crutch and boon to small and medium-sized business in Ukraine. These obstacles to running a business are often in practice motives for finding better conditions for doing business beyond Ukraine and internationalisation business.

\section{The Definition and Contemporary Forms of Internationalisation in Small and Medium-sized Business}

Internationalisation is one way an enterprise can develop. Going international is often a response to a lack of sufficient opportunities to develop business activity within a home market. Often, the economic opportunities are better abroad. Internationalisation comes in response to the existence of specific barriers in a country, the availability of specific motives, development of individual action strategies. In this paper, we have identified the main problems with and necessary prerequisites for the internationalisation of small and medium-sized enterprises in Ukraine in the mid-term perspective. One of the aims of this study was to compare definitions of internationisation used in the subject literature. Table 1 breaks down the results of the answers offered to the questionnaire.

Clearly, internationalisation is defined in multiple ways. Most often, however, the process is understood as one of the internationalisation of operations, then as the export and import of goods and cooperation, international cooperation and the expansion of activities to foreign markets. 
Similarly, there is a multitude of views in the literature, lending to the complexity of the issue. A dominant one is internationalisation understood as any economic activity undertaken by an enterprise abroad (Rymarczyk 2004, p. 19), or as a company's commitment to international activity (Johanson \& Vahlne 1977, p. 26; Przybylska 2005, p. 73), or export and import of products / raw materials or transfer of production outside of the home country (Pietrasieński 2005, p. 15). Internationalisation is certainly a dynamic process (Glinkowska \& Kaczmarek 2016a, pp. 20-27; Welch \& Luostarinen 2013, p. 95). It applies to both domestic companies with assets located only in one and those with assets in two or more countries (Pierścionek 2011, p. 359). As Jarosiński points out, this is a process in which an enterprise enters into relations with other entities to pursue its strategic goals (Jarosiński 2013, p. 19), and is beneficial for the enterprises.

Table 1. Defining Internationalisation

\begin{tabular}{|l|c|}
\hline \multicolumn{1}{|c|}{ The Essence of Internationalisation } & $\begin{array}{c}\text { Number of Answers } \\
N=75\end{array}$ \\
\hline Internationalisation of business activities & 27 \\
\hline $\begin{array}{l}\text { Exporting and importing goods indirectly (in one's own country with } \\
\text { intermediary companies) and directly (with companies from abroad in } \\
\text { one's own country and abroad). }\end{array}$ & 22 \\
\hline $\begin{array}{l}\text { Cooperation between enterprises from different countries (international } \\
\text { cooperation) }\end{array}$ & 18 \\
\hline Expanding into foreign markets (host markets) & 4 \\
\hline Conducting business on foreign markets (direct foreign investment) & 4 \\
\hline
\end{tabular}

Source: the authors, Ukraine, 2019.

The essence of internationalisation is, therefore, conducting business in cooperation with enterprises from abroad as well as through direct foreign investments.

Enterprises operating in Ukraine apply various forms of internationalisation. The term form here should be understood as the method of organising cooperation (co-production, cooperation), commencing operations on foreign markets or with entrepreneurs from outside the home country (Wach 2008, pp. 50-53). Table 2 lists the different forms.

The enterprises surveyed most often use exports (indirect and direct - 58) production co-production (22), followed by import (indirect and direct - 32). Imports and exports are relatively simple forms that do not require large financial outlays, bringing immediate positive economic results. Cooperation and strategic alliances require well-developed contracts, trust and close common effort within the framework of joint projects. They too often yield positive economic results, but only after some time, making them less attractive for enterprises with limited 
equity. In addition, more complex forms require greater company involvement abroad and a higher scope of oversight (Rymarczyk 2004, p. 156), both of which require more time and financial resources.

Table 2. Forms of Internationalisation Used by Ukrainian Organisations

\begin{tabular}{|l|c|}
\hline \multicolumn{1}{|c|}{ Form of Internationalisation } & $\begin{array}{c}\text { Number of Enterprises } \\
(N=75)\end{array}$ \\
\hline Indirect import (through an intermediary) & 14 \\
\hline Direct import (in person, directly) & 19 \\
\hline Indirect export (through intermediary) & 26 \\
\hline Direct export (in person, directly) & 32 \\
\hline Co-production & 22 \\
\hline Strategic alliance & 8 \\
\hline License & 0 \\
\hline Franchising & 0 \\
\hline Direct foreign investment & 0 \\
\hline
\end{tabular}

Note: multiple choices possible.

Source: the authors, Ukraine, 2019.

For Ukrainian small and medium-sized businesses, the lack of sufficient capital for FDI or the development of activities on its own market weighs heavily. Ukrainian companies face fierce, unformalised competition at home, due mainly to the fact that many Ukrainian companies engage in unregistered - grey zone - activities. The low operating costs such companies enjoy are reflected in low market prices they take for their products and services - prices well below what registered entities operating legally are able to take. This leaves the latter companies less attractive but more motivated to seek opportunities outside of their domestic market. Export and import are also sometimes the basis for the development of cooperation or a strategic alliance.

\section{Motives for and Barriers to Internationalisation for Ukrainian SMEs}

Motives and determinants of and barriers to internationalisation should be considered in the light of the following:

- operating and development conditions on the home market (Glinkowska \& Kaczmarek 2016b, p. 125),

- the possibilities of functioning and developing on a foreign, or host country, market (Glinkowska \& Kaczmarek 2016b, p. 125), 
- the strength, quantity and quality of assets under control,

- the number, strength and quality of the company's weaknesses.

This requires the company to carry out a SWOT analysis - an analysis of strengths, weaknesses, opportunities and threats in the environment (Gierszewska \& Romanowska 2017, p. 113) of both home and host countries - is an essential step in addressed the above issues. Such analyses are advisable for both the company as a whole and the products they offer. The SWOT analysis carried out in the process of studying Ukrainian enterprises and further processing the materials on the results of surveys of experts / analysts showed the following. Among Ukrainian SMEs, several weaknesses dominate. These include the lack of own capital and lack of modern advanced technologies (for resources, marketing and management, that owners of small and medium-sized businesses in the course of our survey have especially emphasised). The companies surveyed listed strengths including high-quality products and / or services, low production costs and traditional recipes. These strengths were of great importance to the entrepreneurs. The threats included: minimal external financing, the large "grey zone" on the home market, unfavourable legal regulations for small and medium-sized businesses, excessive appreciation of large companies at the expense of their smaller counterparts, the low incomes in Ukraine, hostilities and the attendant lack of favourable conditions for trade in some regions (Donetsk, Luhansk).

Table 3. Motivations for Ukrainian Enterprises to Internationalise

\begin{tabular}{|l|c|}
\hline \multicolumn{1}{|c|}{ Motives to Internationalisation } & $\begin{array}{c}\text { Number of Enterprises } \\
(N=75)\end{array}$ \\
\hline Increased revenues and net profits & 75 \\
\hline Opportunity to develop & 52 \\
\hline Limited sales opportunities and strong competition on home market & 67 \\
\hline Willingness to find a niche for one's products on host market/markets & 18 \\
\hline Access to new technologies & 16 \\
\hline Legal loopholes & 4 \\
\hline Favourable legal regulations on host market & 10 \\
\hline Unfavourable legal regulations on home market & 48 \\
\hline Prestige, status & 8 \\
\hline Personal motives and knowledge on host market & 42 \\
\hline $\begin{array}{l}\text { Lack of raw materials/supplies on home market or lower prices on host } \\
\text { market }\end{array}$ & 22 \\
\hline
\end{tabular}

Note: multiple choices possible.

Source: the authors, Ukraine, 2019. 
On foreign markets, on the other hand, threats include complicated regulations, the need to make costly adjustments to meet the requirements of a given market and high financial penalties for legal irregularities. Opportunities on markets of host countries are primarily seen in liberalised conditions for trade and globalisation processes. In the light of the SWOT analysis, Table 3 contains the most important motivations for the internationalisation among Ukrainian SMEs, while Table 4 breaks down the barriers.

The analysis of the data in Table 3 shows that the main motivations for the internationalisation of activities for small and medium-sized enterprises in Ukraine are: increased revenues (75 responses), limited opportunities to sell their products in the domestic market (67), opportunities to develop operations outside one's home country (52), and unfavourable legal regulations on one's home market (48). The motives for the internationalisation of Ukrainian small and medium-sized businesses result primarily from the inability of entrepreneurs to develop their own business in the Ukrainian market and the related lack of opportunity to turn a decent profit.

Table 4. Barriers to Internationalisation for Ukrainian Enterprises

\begin{tabular}{|l|c|}
\hline \multicolumn{1}{|c|}{ Barriers } & $\begin{array}{c}\text { Number of Enterprises } \\
(N=75)\end{array}$ \\
\hline No information on host market or markets/fear of mistakes/penalties & 49 \\
\hline Lack of awareness of regulations in host country & 40 \\
\hline Not understanding language of host country & 36 \\
\hline High taxes/ duties on host market/markets & 31 \\
\hline Insufficient quality of one's own products/services & 14 \\
\hline Transport and delivery costs & 17 \\
\hline Lack of private equity & 75 \\
\hline Fear that partners will be unreliable & 45 \\
\hline Personal barriers (eg. lack of faith in one's own abilities) & 17 \\
\hline
\end{tabular}

Note: multiple choices possible.

Source: the authors, Ukraine, 2019.

Ukrainian small and medium-sized enterprise entrepreneurs are open to international cooperation, but lack information on the legal, economic and cultural opportunities to develop operations in host markets. They also lack adequate equity, and fear that potential partners may be unreliable, thus hindering their foreign expansion. The present research leads to the conclusion that the entrepreneurs do not believe ignorance of a given foreign language or transport costs are crucial barriers. 


\section{Prospective Strategies and Mechanisms for Activating Small and Medium-sized Business in Ukraine}

The strategy concerns a well-thought-out, relatively permanent action plan and guidelines for dealing with the implementation of organisational goals and the shaping of organisational identity (Obłój 2007, pp. 325-337). Research we carried out in 2015-2019 allowed us to conclude that small and medium-sized companies in Ukraine usually use four basic types of strategy (multiple choices possible): competing on price (75); competing on quality (59); competing with the use of technology (39); specialised activities (31). A single company can deploy all of these strategies, though they most often compete in price and quality. A low-price strategy is possible thanks to low production costs (lower than in other countries, eg. Western Europe). Competing with technology is understood here as support for activities based on traditional technologies (including hand-made products) and old recipes. A main strength for enterprises which produce mainly food supplies would be a lack of changes being made both to their technologies and recipes.

Strategies such as competing costs, knowledge, competences, or business diversification have marginal significance in the cases analysed for this paper. Such strategic behaviors may result from the desire to locate one's own products / services in countries with a higher level of technology. Doing so allows a company to develop and benefit from a higher margin on its product. 30 of the enterprises surveyed for this research indicated as much. The enterprises rarely make comprehensive strategic analyses of their own operations, lacking the time and money to do so. They cannot afford to reorganise structures in order to separate positions or organisational units dealing with foreign expansion. They are dominated by large companies and often by small and medium-sized companies operating in the black.

Based on the results of the research done in the sample of small and medium-sized Ukrainian enterprises, conclusions can be drawn as to the basic and most frequent ways they internationalise. It seems that the aspects that have the greatest influence on the way of entering the foreign market are: motives and barriers to internationalisation as well as forms and strategies of this process. The surveyed enterprises do not use stages in their internationalisation attempts. In general, small businesses in Ukraine are not subject to phases of internationalisation. The same is true for medium-sized companies, but here the phase is a more frequent phenomenon.

After the initial stage of production and commercial activities, a significant part of Ukrainian small and medium-sized enterprises begins to look for opportunities to enter the foreign market. Again, this is mainly due to the lack of sufficient 
opportunities to develop entrepreneurial activity on the home market combined with the illegal operations of small and medium-sized businesses and the lower operating costs they enjoy. Thus, they exhibit features of the born global model (global from the beginning, born as global).

This means that during the initial phase, the company's first foreign contacts are established (mostly through acquaintances, friends and family members). Fast and early internationalisation is bolstered by the skills and charisma of business owners and managers. Small and medium-sized companies relatively often establish cooperation with companies from countries neighbouring Ukraine, often with the character of commodity turnover (export-import) and production cooperation. These are enterprises that usually do not have enough capital to create FDI, and their activity is often based not on innovative projects, but on products and services that compete on price. However, they do not rule out strategic alliances as a complex form of internationalisation and are not afraid of the quality of their own products.

The research carried out by the Center for Research Cooperation PolandUkraine, was done in part to offer practical recommendations. Using our preliminary results, in 2018 we presented our proposals to the Starobelsk State District Administration of the Luhansk region and to the Verkhovna Rada of Ukraine Committee on State Building, Regional Policy and Local Self-Government of the Verkhovna Rada of Ukraine. This was called to optimise the state regulatory policy in the field of small and medium entrepreneurship and attract international investments in the country's economy. The proposals were accepted for implementation into the state's regulatory policy.

From these institutions, the Center for Research Cooperation Poland-Ukraine received proposals for the continuation and deepening of the research. These concerned the adaptation in Ukraine of EU policy on regulating activities of small and medium-sized enterprises; improving interaction between the local, regional and state authorities in relation to small and medium-sized businesses; suggesting recommendations on the cross-cultural communications between the business communities of Poland and Ukraine.

\section{Research Conclusions}

The results of the study allow us to draw the following conclusions.

The theoretical, methodological and applied practical research suggests that the internationalisation of Ukrainian small and medium-sized enterprises is at an early stage. It does not go much beyond export-import operations. 
This conclusion, based on the presented theoretical and empirical studies, is confirmed by a general assessment of the level of development of integration processes that are characteristic of modern Ukrainian economic science.

At the same time, a certain lack of practical information about the potential host country and the absence of sufficient common equity are the main obstacles faced by small and medium-sized Ukrainian companies seeking to internationalise. A lack of knowledge of foreign markets is yet another significant barrier to entering other host markets.

The unfavourable conditions for conducting business in Ukraine (especially for small and medium-sized businesses) is the main determinant pushing companies to go international and seek opportunities beyond Ukraine. Entrepreneurship and the determination of business owners (and managers) also play a role. When small and medium-sized Ukrainian companies internationalise, they tend to do so early in their existence, or even immediately. This is a response to the lack of opportunities available in Ukraine and their inability to compete with their grey-market counterparts. The development of effective state regulatory policy governing and guiding SMEs on the contemporary norms and standards of the European Union will be the main stimulant of internationalisation and the main boost to its socio-economic impact. The results of this study have shown that Ukrainian small and medium-sized enterprises can gain their greatest competitive advantages in the global market in industries including agriculture (primarily, "eco" and "green"), alternative and renewable energy production and IT technologies. The potential capacity of the world economy (and of united Europe in particular) suggests that integrating Polish and Ukrainian small and medium-sized enterprises would be expedient. Both the proximity of the national business cultures of Poland and Ukraine, and the profiles of modern Polish and Ukrainian manager, would also be conducive to successful collaboration between the two countries. Ukraine state regulatory policy governing SMEs would be well advised to adopt a set of measures and mechanisms to stimulate internationalisation. Such measures could include the following four: form a favourable institutional environment for micro-enterprises and SMEs; consider the needs of SMEs; simplify access to financial resources; optimise SME tax policy.

If state regulatory policy is improved, and creation of favourable institutional prerequisites for the internationalisation of Ukrainian SMEs are created, the prospects for the various forms and avenues of SME economic activity developing may reach a qualitatively new level. The same may be said for the sector as a whole.

Further studies will present additional empirical studies both with an increase in the sample size and with the expansion of the geography of empirical studies to cover other regions of Ukraine. This will provide an opportunity to develop effective models for the internationalisation of small and medium-sized business 
in Ukraine, taking into account three features. First, economic activity of SMEs in priority sectors of the national economy. Second, internationalisation with enterprises from countries that are Ukraine's strategic partners (internationalisation with Polish enterprises is of paramount importance here). Third, Polish and Ukrainian enterprises internationalising by pushing into third countries (the markets of Central Asia and the Middle East are the most promising).

\section{Bibliography}

Chukhray N. (2013), Rozwój przedsiębiorczości w Ukrainie - główne problemy oraz perspektywy, „Przedsiębiorczość i Zarządzanie”, SAN, t. XIV, z. 8, cz. 1.

Džabraìlov R., Novìkova V. (2015), Êvropejs'kij dosvìd pravovogo zabezpečennâ pìdtrimki malogo ta seredn'ogo bìznesu u kontekstì regìonalizaciï deržavnogo upravlìnnâ ekonomikoû, Naukovij vìsnik Užgorods'kogo nacìonal'nogo unìversitetu, Serîa "Pravo", Užgorod, no 31, vol. 2.

Epifanova I. (2009), Kluczowe aspekty rozwoju małych przedsiębiorstw na Ukrainie, Materiały Uniwersytetu Odeskiej Politechniki, Odessa, no 1(31).

Gierszewska G., Romanowska M. (2017), Analiza strategiczna przedsiębiorstwa, 7th ed., PWE, Warszawa.

Glinkowska B. (2018), Internacjonalizacja polskich i ukraińskich przedsiębiorstw, Wydawnictwo Uniwersytetu Łódzkiego, Łódź.

Glinkowska B., Kaczmarek B. (2016a), Zarzq̨dzanie międzynarodowe i internacjonalizacja przedsiębiorstw. Teoria i praktyka, Wydawnictwo Uniwersytetu Łódzkiego, Łódź.

Glinkowska B., Kaczmarek B. (2016b), Zarzq̨dzanie międzynarodowe. Strategie $i$ studia przypadków, Wydawnictwo Uniwersytetu Łódzkiego, Łódź.

Glinkowska B., Chebotarov V. (2018), A Comparative Cross-Cultural Analysis of the Profile of a Modern Ukrainian Manager: the Imperatives of the Future in the Context of Internationalization, "Comparative Economic Research. Central and Eastern Europe" (1508-2008), vol. 21, no 3, https://doi.org/10.2478/cer-2018-0019.

Glinkowska B., Chebotarov V. (2019), Establishing a Business in Ukraine - the Initial Regulatory Organizational and Legal Aspects for Polish Entrepreneurs, "Comparative Economic Research. Central and Eastern Europe”, vol. 22, no 1, https://doi. org/10.2478/cer-2019-0005.

Hlinkows'ka B., Chebotariow W. (2016), Malyj i srednij biznes Pol'ši i Ukrainy: problemy klassifikacii i ishodnye institucional'nye osnowy (in:) B. Glinkowska (ed.), Internacjonalizacja przedsiębiorstw. Uwarunkowania, procesy, wyniki badań, Wydawnictwo Uniwersytetu Łódzkiego, Łódź.

Jarosiński M. (2013), Procesy i modele internacjonalizacji polskich przedsiębiorstw, Oficyna Wydawnicza SGH, Warszawa.

Johanson J., Vahlne J. R. (1977), The Internationalization Process of the Firm - A Model of Knowledge Development and Increasing Commitments, "Journal of International Business Studies", vol. 8, no 1, https://doi.org/10.1057/palgrave.jibs.8490676.

Kodeks handlowy Ukrainy nr 436-IV z 16 stycznia 2003 r., Biuletyn Rady Najwyższej Ukrainy, 2003, nr 18, nr 19-20, nr 21-22, art. 144. 
Leh G., İl'čišin M., Turkalo O. (2011), Svìtovij dosvìd rozvitku pìdpriêmstv malogo bìznesu, Naukovij vìsnik NLT Ukraïni: Zbìrnik naukovo-tehnìčnih prac', vip. 21.15.

Lyashenko V., Tolmachova A., Kvilinskyi O. (2016), Państwowa polityka rozwoju przedsiębiorczości w kontekście stabilności społecznoekonomicznej (na przykładzie Ukrainy), „Zeszyty Naukowe Polskiego Towarzystwa Ekonomicznego w Zielonej Górze”, nr 4.

Obłój K. (2007), Strategia organizacji, 2nd ed., PWE, Warszawa.

Orekhova T., Koshelenko V. (2010), Small and medium business development in condition of Ukrainian economy internationalization, "Economics \& Management", no 15.

Pierścionek Z. (2011), Zarzqdzanie strategiczne w przedsiębiorstwie, PWN, Warszawa.

Pietrasieński P. (2005), Międzynarodowe strategie marketingowe, PWE, Warszawa.

Przybylska K. (2005), Proces internacjonalizacji przedsiębiorstwa w teorii ekonomicznej, Zeszyty Naukowe Wyższej Szkoły Ekonomicznej w Bochni, nr 3, Bochnia.

Rymarczyk J. (2004), Internacjonalizacja i globalizacja przedsiębiorstwa, PWE, Warszawa.

Wach K. (2008), Skutki akcesji do Unii Europejskiej dla polskich przedsiębiorstw, Wydawnictwo Uniwersytetu Ekonomicznego w Krakowie, Kraków.

Welch L. S., Luostarinen R. K. (2013), Internationalization: Evolution of a Concept (in:) K. Przybylska (ed.), Born Global. Nowa generacja małych przedsiębiorstw, Fundacja Uniwersytetu Ekonomicznego w Krakowie, Kraków.

\section{Sposoby internacjonalizacji małych i średnich przedsiębiorstw na Ukrainie} (Streszczenie)

Cel: Celami prezentowanego badania są: klasyfikacja poziomu rozwoju internacjonalizacji małych i średnich przedsiębiorstw na Ukrainie poprzez analizę materiału teoretycznego istniejącego w nauce oraz przedstawienie własnych badań empirycznych autorów przeprowadzonych wśród ukraińskich małych i średnich przedsiębiorstw; przeanalizowanie głównych form, czynników motywacyjnych i barier internacjonalizacji ukraińskich MŚP; uzyskanie podstawy do opracowania strategii i mechanizmów aktywizacji internacjonalizacji małych i średnich przedsiębiorstw na Ukrainie.

Metodyka badań: W badaniach wykorzystano metody badań jakościowych: badania literaturowe oraz własne badania empiryczne (szczegółowe wywiady z ukraińskimi przedsiębiorcami, kwestionariusz ankietowy, a także eksperckie oceny naukowców z Ukrainy i Polski na ten temat).

Wyniki badań: W wyniku zrealizowanych badań oceniono rzeczywisty stan internacjonalizacji ukraińskich MŚP, zidentyfikowano bariery i motywy tego procesu. Zostały sklasyfikowane najbardziej obiecujące strategie i sektory gospodarki, w których ukraińskie małe przedsiębiorstwa powinny uzyskać największą przewagę konkurencyjną w nowoczesnym międzynarodowym podziale pracy, oraz zdefiniowano mechanizmy promujące internacjonalizację ukraińskich małych i średnich przedsiębiorstw.

Wnioski: W nowoczesnych warunkach umiędzynarodowienie ukraińskich małych i średnich przedsiębiorstw jest na wczesnym etapie. Praktycznie nie wykracza poza ramy operacji eksportowo-importowych. Na Ukrainie dominującym sposobem umiędzynarodowienia małych i średnich przedsiębiorstw jest ich wczesna (lub natychmiastowa) interna- 
cjonalizacja. Głównym kierunkiem stymulowania internacjonalizacji małego i średniego biznesu na Ukrainie jest rozwój skutecznej polityki regulacyjnej państwa dostosowanej do współczesnych norm i standardów Unii Europejskiej. Ze względu na strukturę kompleksu gospodarczego Ukrainy i cechy nowoczesnego międzynarodowego podziału pracy ukraińskie małe i średnie przedsiębiorstwa mogą uzyskać największą przewagę konkurencyjną na rynku globalnym w takich branżach, jak: rolnictwo (przede wszystkim „ekologiczne” $\mathrm{i}$,,zielone”), alternatywne i odnawialne źródła energii oraz technologie informatyczne.

Wkład w rozwój dyscypliny: Badania wypełniają lukę naukową w zakresie analizy sposobów internacjonalizacji polskich i ukraińskich małych i średnich przedsiębiorstw.

Słowa kluczowe: internacjonalizacja, przedsiębiorstwo, przedsiębiorczość, małe i średnie przedsiębiorstwa, państwowa polityka regulacyjna, bariery, motywy, strategie, mechanizmy, międzynarodowy podział pracy, Ukraina. 